\title{
ISTRAŽIVANJE ZADOVOLJSTVA KORISNIKA VISOKOŠKOLSKE KNJIŽNICE
}

\author{
Sanja Grakalić Plenković \\ Dr. sc., docentica, Veleučilište u Rijeci, Vukovarska 58, 51000 Rijeka, Hrvatska; \\ e-mail: sgrakal@veleri.hr \\ Sanja Raspor Janković \\ Dr. sc., prof. visoke škole, Veleučilište u Rijeci, Vukovarska 58, 51000 Rijeka, Hrvatska; \\ e-mail: sraspor@veleri.hr
}

\section{SAŽETAK}

Ocjenjivanje knjižničnih usluga najobjektivniji je način uvida u organizaciju i rad knjižnice. Surha ovog istraživanja bila je istražiti zadovoljstvo korisnika knjižničnih usluga. U tu je svrhu provedeno prikupljanje primarnih podataka na primjeru Knjižnice Veleučilišta u Rijeci. Podaci su prikupljani tehnikom anketiranja. Upitnik za prikupljanje podataka sastojao se od šest dijelova: važnost knjižničnih usluga, zadovoljstvo pojedinom knjižničnom uslugom, uvjeti rada u knjižnici, ukupno zadovoljstvo korisnika knjižnice, lojalnost korisnika knjižnice i profil ispitanika. Uzorak čine studenti preddiplomskih i specijalističkih diplomskih stručnih studija, a podaci su prikupljeni u razdoblju od siječnja do studenoga 2020. godine. U analizi prikupljenih podataka korištene su metode deskriptivne statistike, t-test i regresijska analiza. Rezultati deskriptivne analize pokazali su orijentiranost korisnika knjižničnom osoblju, preko kojeg se najčěčce informiraju o radu Knjižnice. Pronalazak literature najvažnija je knjižnična usluga. Ukupno zadovoljstvo korisnika knjižnice ocijenjeno je prosječnom ocjenom 4,55, što pokazuje visok stupanj zadovoljstva uslugama u promatranoj knjižnici. Na temelju provedenog t-testa moguće je zaključiti da korisnici knjižnice koji studiraju na različitim razinama studija imaju značajno različite stupnjeve zadovoljstva pojedinom knjižničnom uslugom, dok obje grupe slično ocjenjuju ukupno zadovoljstvo knjižnicom. Nadalje, postoji statistički značajna povezanost između zadovoljstva pojedinom knjižničnom uslugom i ukupnog zadovoljstva korisnika knjižnice. Također su značajno povezani ukupno zadovoljstvo i lojalnost korisnika knjižnice. Provedeno istraživanje pridonijelo je boljem razumijevanju stavova o knjižničnim uslugama, te je slijedom toga pokazalo niz prijedloga temeljem kojih Knjižnica može redefinirati poslovanje, uvjete rada i usluga i uskladiti ih s prijedlozima korisnika, a s ciljem poboljšanja razine zadovoljstva i postizanja pozitivnih namjera u ponašanju.

Ključne riječi: zadovoljstvo korisnika, kvaliteta knjižnične usluge, ocjenjivanje knjižničnih usluga, visokoškolska knjižnica, kvantitativna analiza 


\section{UVOD}

Visokoškolska knjižnica korisniku nudi raznolike usluge (uz najvažniju uslugu vezanu uz posudbu, spomenimo informacije o građi, pomoć u pretraživanju knjižničnih kataloga i upućivanje na samostalno pronalaženje građe $i$ informacija, njihovo selektiranje i vrednovanje, pretraživanje raznih baza podataka, izravni dodir s građom itd.). Povratna informacija od korisnika knjižnice ističe se kao jedna od važnih i vrijednih smjernica u valorizaciji postojećih te uvođenju pojedinih novih usluga i načinu njihove organizacije, uopće poslovanju i prioritetima u organizaciji visokoškolske knjižnice. Vrednovanje knjižničnih usluga jedan je od objektivnih načina na koji se može sagledati poslovanje i organizacija knjižnice, koji se kasnije mogu posebno usmjeriti na uspješnije upravljanje knjižnicom i ispreplesti s daljnjim planiranjem u izradi strateškog plana knjižnice za neko sljedeće određeno vremensko razdoblje. Visokoškolske knjižnice, stoga, vrlo često ispituju zadovoljstvo svojih korisnika pruženim uslugama, služeći se rezultatima takvih istraživanja kao pokazateljima uspješnosti svoga rada.

Vrednovanja knjižnice, s obzirom na različito definiranje kvalitete visokoškolskih knjižnica, Pikić definira kroz tri pristupa (Pikić, 2016:112-113); 1) vrednovanja koja su povezana s ispitivanjem ekonomičnosti i adekvatnosti poslovanja knjižnica (kvalitetu definiraju kao uspješnost knjižnice da svojim karakteristikama poslovanja/aktivnostima dokaže ekonomičnost i adekvatnost svojih resursa za informacijske potrebe svojih korisnika (Petr Balog, 2010), ukratko, knjižnica bi bila kvalitetna ako posluje poštujući optimalan odnos troškova i rezultata poslovanja'; 2) drugi pristup u vrednovanju knjižnica kvalitetu definira kao stupanj utjecaja knjižnica u okruženju u kojem djeluju, na svoje korisnike i užu i širu zajednicu, obrazujući i informirajući, ostvarujući akademski uspjeh, šireći informacijsku pismenost i sl.2; 3) treći način pristupa vrednovanju knjižnice na temelju povratnih informacija vezanih uz zadovoljstvo korisnika knjižničnom uslugom, odnosno njihova stava o razini kvalitete knjižnične usluge definirana iz perspektive različitih knjižničnih dionika, koji ocjenjuju koliko je knjižnica svojim uslugama zadovoljila njihove potrebe, od informacijskih do pružanja građe, procjenjuju omjer ili u kojoj je mjeri dobivena knjižnična usluga/aktivnost u skladu s korisničkim očekivanjima, od posudbe građe do informacijskih usluga, prostora, opreme, kompetentnosti osoblja ${ }^{3}$. Istraživanja koja ispituju zadovoljstvo korisnika česta su (McKnight, 2006; Oakleaf, 2010; Atkinson, 2017) i u Hrvatskoj vrlo popularna (Petr, 2000; Barada, Zdravković, 2009; Dukić et al., 2009; Badurina, DragijaIvanović, 2010; Novak, 2010; Petr Balog, 2010; Petr Balog et al., 2010; Petr Balog, Plašćak, 2012; Radičević, 2013; Aleksić, Seiter-Šverko, 2014; Petr Balog, Gašo, 2016; Pikić, 2016; Moslavac, 2017; Pikić, 2017; Franculić, 2018).

1 Ova se vrednovanja knjižnične djelatnosti temelje na pokazateljima uspješnosti međunarodnih i hrvatskih standarda, a to su za vrednovanje knjižnične djelatnosti norma HRN ISO 11620 (1998, 2003, 2008, 2014) „Informacije i dokumentacija - pokazatelji učinka knjižnica“ i HRN ISO 2789 (1991, 2003, 2006, 2013) „Informacije i dokumentacija - međunarodna knjižnična statistika" (Martek, 2009).

2 Vrednovanja knjižnica u tom smislu podrazumijevaju istraživanja kao što su citatna analiza objavljenih radova nastavničkog osoblja ili studentskih završnih radova, testiranja informacijske pismenosti, analiza znanstvene produkcije ustanove u čijem je sastavu knjižnica i sl.

3 Neki od popularnih anketnih alata za ovakav pristup su, primjerice, SCONUL Satisfaction Survey, LibQUAL+, SERVQUAL, WebQUAL. 


\section{TEORIJSKA OSNOVA ISTRAŽIVANJA}

Zadovoljstvo klijenta može se promatrati s različitih stajališta, zbog čega postoji i niz definicija ovog koncepta. Fornell (1992) definira zadovoljstvo klijenta kao ukupnu ocjenu kupovine. Oliver (1997) navodi da se radi o klijentovu sudu o tome jesu li proizvod ili usluga pružili ugodnu razinu ispunjenja, dok Zeithaml i Bitner (2003) smatraju da je zadovoljstvo klijenta njegova subjektivna ocjena proizvoda ili usluge o tome, ispunjavaju li ti proizvodi ili usluge njegova očekivanja i potrebe. lako pregled literature ukazuje na razlike u pojedinim definicijama zadovoljstva klijenta, Giese i Cote (2000) zaključuju da sve definicije imaju sljedeće zajedničke elemente: 1) zadovoljstvo klijenta je reakcija (emocionalna ili spoznajna); 2) reakcija se odnosi na određeni element klijentova zadovoljstva (očekivanja, proizvod/usluga, iskustvo kupovine i sl.); 3) reakcija nastaje u određenom trenutku (nakon korištenja, na temelju prijašnjih iskustava i sl.).

U konceptualizaciji zadovoljstva klijenta potrebno je ukazati i na povezanost s kvalitetom usluge, kao njegovom prethodnicom, te $s$ lojalnošću klijenta kao njegovom važnom posljedicom. Percipirana kvaliteta je klijentov stav o superiornosti usluge ili proizvoda (Zeithaml, 1988). Ona, dakle, odražava doživljenu, stvarno pruženu uslugu. To je spoznajna mjera koja dovodi do zadovoljstva klijenta. Pozitivna veza između kvalitete usluga i zadovoljstva klijenta dokazana je i na primjeru usluga i korisnika knjižnica (primjerice, Choshaly i Mirabolghasemi, 2018; GómezCruz, 2019). S druge strane, Kandampully i Suhartanto (2000) navode da lojalan klijent kupuje od istog proizvođača proizvoda ili pružatelja usluga kada god je to moguće, taj proizvod ili uslugu preporučuje drugima i ima pozitivan stav prema poduzeću. Istraživanja su pokazala (primjerice Fornell, 1992; Kandampully i Suhartanto, 2000; Coker, 2013; Xu i Du, 2018) da se zadovoljni klijenti vraćaju, ponovno kupuju i koriste već poznate proizvode i usluge te pozitivno govore o svom iskustvu.

Pristup vrednovanju knjižnice na temelju povratnih informacija vezanih uz zadovoljstvo korisnika knjižničnom uslugom primijenjen je i u našem istraživanju vrednovanja zadovoljstva korisnika, a time i kvalitete. Kvalitetnom drži knjižnicu „と̌iji su korisnici zadovoljni opsegom i izvedbom knjižničnih usluga ili koji procjenjuju da je dobivena usluga u knjižnici ispunila ili čak nadmašila njihova očekivanja" (Pikić, 2016:113).

Kvaliteta usluge i zadovoljstvo korisnika knjižnice, dakle, mogu se poimati povezano, no zadovoljstvo podrazumijeva širu predodžbu od kvalitete usluge, koju najčěšce povezujemo uz određene specifične i različite komponente ili dimenzije određene usluge (Kiran, Diljit, 2011). U kontekstu usluga visokoškolskih knjižnica zadovoljstvo korisnika može biti više ili manje povezano uz poslovanje knjižnice, poput zadovoljstva opremljenošću knjižnice, opsegom zbirke ili dostupnošću naslova obvezne ispitne literature, brojem primjeraka, zadovoljstvo dostupnošću stranih časopisa i sl. ili zadovoljstvo samom uslugom, brzinom komunikacije osoblja knjižnice u rješavanju upita, načinima slanja obavijesti o dostupnosti građe, komunikacijom knjižničara s korisnicima, pomoći u pretraživanju, kompetentnost i stručnost osoblja. Posljedično, visok stupanj zadovoljstva uslugama odrazit će se na posjećenost knjižnice i lojalnost korisnika, ali i dokazati da je zadovoljstvo korisnika knjižnice kategorija fluidnih karakteristika, temeljenih na sveukupnom trudu njenih zaposlenika, stoga ne mora uvijek biti posljedica financijskih mogućnosti knjižnice i 
njezina ulaganja u opseg građe. Naime, možemo razlikovati korisnika koji ispunjen nezadovoljstvom izlazi iz knjižnice jer knjiga koju treba nije dio knjižničnog fonda ili je već na posudbi, od korisnika koji također nije posudio željeni naslov, ali mu je knjižničar posvetio svoju pažnju i ponudio svoje znanje, pretražujući kataloge i baze podataka, ne bi li pokušao pronaći zamjensku relevantnu literaturu, zabilježio kontakte kako bi ga obavijestio kada posuđena građa bude opet dostupna na vrijeme i bez odgađanja ili uputio studenta na knjižnicu u kojoj je građa dostupna i sl. i koji, u konačnici, osjeća pomoći trud knjižničara kao pozitivni odjek.

Intencija istraživanja prikazanog u ovom radu jest da njegovi rezultati u budućnosti pridonesu poboljšanju rada visokoškolske knjižnice čije zadovoljstvo korisnika istražujemo, Knjižnice Veleučilišta u Rijeci. Naime, specifični su razlozi dolaska korisnika u svaku visokoškolsku knjižnicu, a s obzirom na to, različita su i njihova očekivanja, a nejednaka poimanja o kvaliteti i neujednačena očekivanja rezultiraju različitim stupnjevima zadovoljstva. Jedan od razloga različitih očekivanja korisnika povezujemo uz činjenicu da, iako su svi ispitani aktivni korisnici Knjižnice Veleučilišta u Rijeci studenti, imaju, s obzirom na njihova prethodna iskustva vezana uz usluge knjižnice, nejednaka očekivanja. Dakle, ne smijemo zaboraviti da je grupa studenata koju anketiramo posve heterogena s obzirom na stavove o kvaliteti, pa posljedično, imaju i različit osjećaj zadovoljstva primljenim uslugom. Valja, stoga, naglasiti razliku u očekivanjima o uslugama knjižnice među studentima koji su prije studija bili korisnici srednjoškolske knjižnice koju su odlikovali skromniji knjižnični fond, odsustvo kataloga i radno vrijeme od nekoliko sati dnevno, od stavova onih koji su bili korisnicima vrlo opremljene srednjoškolske knjižnice, bogatog, katalogiziranog knjižničnog fonda i dvosmjenskog radnog vremena.

Vezano uz studij i znanstveni i stručni rad studenata, očekivanja obuhvaćaju njihovu potrebu za literaturom i uvidom u knjižnični fond, za knjižničnim uslugama, tematskim pretraživanjima, pretraživanjima kataloga, baza podataka, zatim potrebe vezane uz uvjete u kojima radi knjižnica, uz mogućnosti samostalnog ili grupnog rada u knjižnici, potrebe za edukacijom korisnika, informacijama o dostupnosti literature, pronalasku odgovarajuće literature potrebne za pisanje radova i istraživanje i sl.

\section{KNJIŽNICA VELEUČILIŠTA U RIJECI}

Knjižnica, kao i samo Veleučilište u Rijeci, osnovana je prije više od dva desetljeća, a danas djeluje na prostoru sveukupne površine $114 \mathrm{~m}^{2}$ (uključuje prostor knjižničnog zatvorenog i otvorenog fonda, referentne zbirke, čitaonice (20 radnih mjesta namijenjenih korisnicima za pretraživanje kataloga, izradu seminara, rad na instaliranim programima koji prate potrebe nastave), prostor za grupno učenje i individualni rad, prostor zatvorenog spremišta, skriptarnicu i prostor za osoblje Knjižnice) $)^{4}$. Čitaonica je opremljena s petnaestak radnih mjesta s računalima za samostalni rad, koja imaju pristup online katalozima, bazama podataka koje su u pretplati Ministarstva znanosti i obrazovanja i ostalim elektroničkim izvorima dostupnima na Veleučilištu u Rijeci. Fond Knjižnice je interdisciplinaran, a proširuje se u skladu sa sadržajima koji se proučavaju na Veleučilištu (tehničke, biotehničke, prirodne, društvene i interdisciplinarne znanosti te mala zbirka

4 Područni odjeli Knjižnice smješteni su na pojedinim odjelima u Poreču i Pazinu i djeluju u knjižnicama ustanova u kojima se održavaju predavanja za studente. 
humanističko-umjetničke tematike). Od 2015. godine Knjižnica je uključena u Digitalni akademski arhiv i repozitorij Dabar. U Knjižnici je zaposlena voditeljica Knjižnice, uz studenta koji u svojstvu pomoćnog knjižničara pomaže u posudbi i razduživanju građe.

Prema podacima iz online kataloga Crolist i arhive Knjižnice Veleučilišta u Rijeci knjižnični fond se krajem 2020. sastoji od 7000 svezaka monografskih publikacija, a knjižnica je pretplaćena na 30-ak stranih i domaćih časopisa (ukupno 380 svezaka periodike). Više od 1900 završnih i specijalističkih završnih radova obranjenih na Veleučilištu od 2015. javno je dostupno u Digitalnom repozitoriju Veleučilišta DabarVeleRi, koji se od dana uspostave redovito popunjava novim ocjenskim radovima, a odnedavno i radovima nastavnika, ako su dostupni u smislu autorskih prava. Literatura koju Knjižnica ne posjeduje nabavlja se međuknjǐnničnom posudbom, a pridruženo članstvo Knjižnice Veleučilišta u integrirani Knjižnični sustav Crolist omogućuje brz kontakt i međuknjižničnu posudbu s knjižnicama u Rijeci i RH, kao i europskima. Posljednja reakreditacija Veleučilišta u Rijeci, provedena od 10. do 12. ožujka 2020., neovisnim vrednovanjem Stručnog povjerenstva ocijenila je usluge Knjižnice visokom razinom kvalitete ${ }^{5}$.

Sukladno stavovima Europske komisije prema kojima se kvaliteta u visokom obrazovanju definira kroz jasan cilj u kontinuiranom pružanju znanja, vještina i kompetencija potrebnih nakon završetka studija, po zapošljavanju ${ }^{6}$, Knjižnica u planiranju svojih budućih aktivnosti teži osuvremenjivanju ijasnom usmjerenju svojih usluga ključnim kompetencijama koje se očekuju od studenata, poput personaliziranog učenja, razvijanja kritičkog razmišljanja i kompetencija koje teže rješavanju problema, te fleksibilnim, inovativnim tehnikama poučavanja i učenja osmišljenima kako bi se povećala djelotvornost obrazovanja i kapaciteti studenata visokih učilišta. $U$ tom smislu posebno se u novom obrazovnom okruženju, koje se odlikuje razvojem informacijsko-komunikacijskih tehnologija, čini važnim podvući obrazovnu uloga knjižnice u smislu tendencija razvijanja potrebnih vještina studenata, povezanih uz informacijsku pismenost (usp. Dewey, 1997; Lau 2011; Golenko, Arh, 2020), poput uspješnog pronalaženja informacije, njena učinkovitog vrednovanja te potom i korištenja, uz razvoj i kontinuirano širenje i usavršavanje kritičkog mišljenja kao potke u visokoškolskom i, daljnjem, cjeloživotnom obrazovanju (Špiranec, Banek Zorica 2008). Korištenje IKT-a i poznavanje informacijskih izvora povezano je s korisničkim potrebama, stoga programi informacijskog opismenjavanja postaju preduvjet za uspješno učenje studenata, a time i sve više neizostavni dio rada visokoškolske knjižnice (Candy et al., 1994). Zadovoljstvo korisnika kvalitetom usluga knjižnice povezano uz kompetencije koje uključuju informacijsku pismenost izuzetno su važno polazište.

\section{METODOLOGIJA}

Surha ovog istraživanja bila je istražiti zadovoljstvo korisnika usluga Knjižnice. Iz toga proizlaze sljedeći ciljevi istraživanja: a) ocijeniti stupanj važnosti pojedinih knjižničnih usluga, b) ocijeniti stupanj zadovoljstva korisnika pojedinim knjižničnim uslugama, c) ocijeniti stupanj ukupnog

5 https://www.azvo.hr/hr/vrednovanja/postupci-vrednovanja-u-visokom-obrazovanju/reakreditacija-visokihucilista/rezultati-vrednovanja-rvu (pristupljeno 5. studenoga 2020).

6 Europska komisija. Obrazovanje i izobrazba. Relevantno i visokokvalitetno visoko obrazovanje. Usp. http://ec.europa. eu/education/policy/higher-education/quality-relevance_hr (pristupljeno 5. studenoga 2020). 
zadovoljstva korisnika knjižničnih usluga, d) utvrditi postoji li statistički značajna razlika u stupnju važnosti knjižničnih usluga i stupnju zadovoljstva korisnika s obzirom na razinu studija ispitanika, e) utvrditi prirodu povezanosti zadovoljstva korisnika pojedinim knjižničnim uslugama s ukupnim zadovoljstvom korisnika, f) utvrditi prirodu povezanosti ukupnog zadovoljstva korisnika i njihove lojalnosti prema knjižničnim uslugama.

Kako bi se postigli ciljevi istraživanja, kreiran je anketni upitnik, te su podaci prikupljeni metodom ispitivanja pisanim putem. Temeljem pregleda literature i upitnika koji se inače koriste $u$ knjižnicama kada se provode slična istraživanja (Petr, 2000; Barada, Zdravković, 2009; Dukić et al., 2009; Badurina, Dragija-Ivanović, 2010; Novak, 2010; Petr Balog, 2010; Petr Balog, Plašćak, 2012; Radičević, 2013; Aleksić, Seiter-Šverko, 2014; Petr Balog, Gašo, 2016; Pikić, 2016; Moslavac, 2017; Franculić, 2018), pitanja u upitniku podijeljena su u cjeline koje su dizajnirane za mjerenje važnosti knjižničnih usluga (6 pitanja), zadovoljstva korisnika pojedinom knjižničnom uslugom (8 pitanja), uvjeta rada u knjižnici (6 pitanja), ukupnog zadovoljstva korisnika (1 pitanje) te lojalnosti korisnika (2 pitanja). Sve su varijable mjerene na Likertovoj ljestvici s 5 stupnjeva. Osim toga, upitnik sadrži i tri općenita pitanja o korisnicima usluga (studij ispitanika, učestalost korištenja knjižničnih usluga te način upoznavanja s knjižničnim uslugama).

Istraživanje je provedeno na uzorku studenata kao korisnika Knjižnice Veleučilišta u Rijeci od siječnja do studenoga 2020. godine. Tiskana anketa u knjižnici nudila se korisnicima zainteresiranim za sudjelovanje u istraživanju. Anketa nije bila dostupna u elektroničnom obliku s obzirom na to da se željelo ispitati mišljenje onih korisnika koji aktivno borave u radnom prostoru knjižnice i čitaonici, stoga je dio pitanja bio povezan upravo sa zadovoljstvom vezanim uz sam prostor čitaonice, računala i građu, pa time i usluge koje su samo tamo dostupne. Zaposlenici knjižnice dijelili su upitnik studentima koji su bili spremni sudjelovati u istraživanju, a ispitanici su ispunjene upitnike predavali na za to predviđeno mjesto u knjižnici. Razdoblje prikupljanja podataka obilježeno je epidemiološkim mjerama koje su utjecale i na rad knjižnica, pa je posjet knjižnicama tijekom proljeća i ljeta 2020. bio u većoj mjeri onemogućen, a zahtjevi korisnika su se uglavnom rješavali online (čime usmjerenost „online korisnika“ mijenja fokus na samo dio usluga knjižnice, dakle i stavove o zadovoljstvu i kvaliteti). Navedeno, svakako, otvara prostor za nadopunu i proširenje ankete na cjelokupnu populaciju studenata, bez obzira je li njihov posjet fizički ili virtualni, zatim na nastavno osoblje i vanjske korisnike. Prikupljen je 91 ispravno ispunjen anketni upitnik, te taj uzorak čini osnovu za analizu prikupljenih podataka?

Prikupljeni podaci analizirani su primjenom odabranih metoda deskriptivne, bivarijatne ( $t$-test za nezavisne uzorke, jednostavna regresijska analiza) i multivarijatne statističke analize (multipla regresijska analiza). Metodama deskriptivne statističke analize opisan je uzorak, te su ocijenjene varijable za mjerenje zadovoljstva korisnika knjižničnih usluga. T-test za nezavisne uzorke korišten

7 Zbog neobičnih okolnosti povezanih uz pandemiju, Knjižnica u 2020. nije kontinuirano radila punim kapacitetom, što je za potrebe ovog rada važno istaći, u smislu reduciranog dolaska korisnika u sam prostor Knjižnice. Broj ukupnih fizičkih posjeta Knjižnici za navedeno razdoblje iznosi 889 posudbi (statistika prema katalogu Crolist za 2020.), dakle ispitano je 10 \% korisnika. Broj posjetitelja u siječnju i veljači 2020. bio je podjednak onome u 2019., no u razdoblju od sredine ožujka do početka rujna knjižnica je bila otvorena samo za virtualne usluge, da bi se od rujna nadalje otvorila djelomično, samo za korisnike koji građu naručuju unaprijed i dolaze uz najavu e-mailom u točno određenim vremenskim intervalima, kako bi se zadovoljile protuepidemiološke mjere. 
je za utvrđivanje statistički značajne razlike u stupnju važnosti knjižničnih usluga i stupnju zadovoljstva korisnika s obzirom na razinu studija ispitanika. Jednostavnom regresijskom analizom provedeno je ispitivanje povezanosti između ukupnog zadovoljstva korisnika i njihove lojalnosti prema knjižničnim uslugama. Primjenom multiple regresijske analize testirana je povezanost između zadovoljstva korisnika pojedinim knjižničnim uslugama i ukupnog zadovoljstva korisnika knjižnice.

\section{REZULTATI}

U ovom dijelu rada prikazani su rezultati provedene statističke analize. Prvo je opisan uzorak. Zatim su prezentirani rezultati ocjenjivanja zadovoljstva korisnika knjižničnih usluga. Slijedi usporedba stupnja zadovoljstva korisnika s obzirom na razinu studija ispitanika. Na kraju je ispitana povezanost između zadovoljstva korisnika pojedinim knjižničnim uslugama i ukupnog zadovoljstva korisnika, te povezanost ukupnog zadovoljstva korisnika i njihovih namjera u ponašanju prema knjižničnim uslugama.

\section{1 Korisnici Knjižnice}

Opis uzorka prikazuje tablica 1.

Tablica 1. Opis uzorka

\begin{tabular}{|c|c|c|}
\hline \multicolumn{1}{|c|}{ Varijabla } & Postotak \\
\hline \multirow{4}{*}{ Studij } & Preddiplomski stručni studij Informatika & 12,1 \\
\cline { 2 - 3 } & $\begin{array}{c}\text { Specijalistički diplomski stručni studij Informacijske } \\
\text { tehnologije u poslovnim sustavima }\end{array}$ & 12,1 \\
\cline { 2 - 4 } & Preddiplomski stručni studij Poduzetništvo & 12,1 \\
\cline { 2 - 4 } & Specijalistički diplomski stručni studij Poduzetništvo & 15,4 \\
\cline { 2 - 3 } & Preddiplomski stručni studij Promet & 14,3 \\
\cline { 2 - 4 } & Specijalistički diplomski stručni studij Promet & 11,0 \\
\cline { 2 - 3 } & Preddiplomski stručni studij Sigurnost na radu & 9,9 \\
\cline { 2 - 3 } & Specijalistički diplomski stručni studij Sigurnost na radu & 4,4 \\
\cline { 2 - 3 } & Preddiplomski stručni studij Telematika & 8,8 \\
\hline
\end{tabular}


S. Grakalić Plenković, S. Raspor Janković: Istraživanje zadovoljstva korisnika visokoškolske knjižnice Zbornik Veleučilišta u Rijeci, Vol. 9 (2021), No. 1, pp. 97-117

\begin{tabular}{|c|c|c|}
\hline \multicolumn{1}{|c|}{ Varijabla } & Postotak \\
\hline \multirow{4}{*}{$\begin{array}{c}\text { Učestalost } \\
\text { posjeta knjižnici }\end{array}$} & Više puta tjedno & 17,6 \\
\cline { 2 - 3 } & Jednom tjedno & 17,6 \\
\cline { 2 - 3 } & Jednom mjesečno & 11,0 \\
\cline { 2 - 3 } & Više puta mjesečno & 27,5 \\
\cline { 2 - 3 } & Svakih nekoliko mjeseci & 13,2 \\
\hline \multirow{2}{*}{$\begin{array}{c}\text { Način } \\
\text { upoznavanja } \\
\text { s knjižničnim } \\
\text { uslugama }\end{array}$} & Jednom u semestru & 13,2 \\
\cline { 2 - 3 } & Informacija od nastavnog osoblja & 17,6 \\
\cline { 2 - 3 } & Putem mrežne stranice knjižnice & 39,6 \\
\cline { 2 - 3 } & Informacija od knjižničnog osoblja & 49,5 \\
\hline
\end{tabular}

Izvor: autorice (2020)

Iz tablice 1 vidljivo je da uzorak obuhvaća studente stručnih i specijalističkih studija koji najčešće u knjižnicu dolaze na tjednoj bazi ili nekoliko puta mjesečno. Studenti se najčešće s knjižničnim uslugama upoznaju na temelju informacija koje dobiju od knjižničnog osoblja. Oko 40 \% ispitanika o uslugama se informira na mrežnim stranicama Knjižnice. Također, bitan izvor informacija je i prethodno iskustvo drugih studenata, tj. razmjena informacija studenata među sobom.

Ovakav odgovor ne iznenađuje, s obzirom na to da Knjižnica, s početkom nove akademske godine otvara svoja vrata novim korisnicima, informirajući svaku novu studijsku grupu studenata na prvoj godini, na uvodnim predavanjima, o mogućnostima i načinima korištenja Knjižnice Veleučilišta, specijalizirano vezano uz određeni studij.

Anketa također pokazuje da studenti najmanje informacija o Knjižnici dobivaju od nastavnog osoblja i posredstvom mrežnih stranica knjižnice, na što se zanimljivo osvrnuti s obzirom na dvije činjenice. Naime, iako se unazad tri desetljeća većina marketinške komunikacije knjižnica s korisnicima općenito odvijala posredstvom masovnih medija, istraživanja marketinga u kulturi ukazuju na neučinkovitost takva pristupa, upravo zbog njegove neselektivnosti i pristupu koji podrazumijeva nedovoljnu definiranost ciljanih skupina (Mi, Nesta, 2006; Pavičić et al., 2006:204). Treba, stoga, komunicirati individualno, obraćajući se korisniku usluge, u našem slučaju studentu, kao pojedincu s posebnim, profiliranim upitima ${ }^{8}$. lako je za općenitije informacije, poput onih o radnim vremenu, uslugama i načinima kontaktiranja s knjižnicom mrežna stranica izvrstan medij, ona nikako ne može biti i jedini i najvažniji način komunikacije s osobljem knjižnice (Vrana, Pavić, 2017), što je i potvrđeno u našem istraživanju. Rezultat, također, potvrđuje da su korisnici, unatoč uvriježenom mišljenju da je u današnje vrijeme informatizacije dostupnost informacija puno šira i sadržajnija, svjesni da je izravni kontakt s knjižničarom najbrža i najtočnija informacija. Ovakav pristup dokazuje da je brzina informiranja u akademskom

8 lako se, u smislu individualizacije komunikacije, naglašava važnost da, zbog brze i lake komunikacije koju omogućuju, knjižnice promoviraju svoje usluga na društvenim mrežama (Vrana, Pavić, 2017), recentno istraživanje ukazuje da one nisu dovoljno zastupljene među visokoškolskim knjižnicama u Hrvatskoj. Profil na Facebooku, tako, posjeduju sve sveučilišne knjižnice, dok ih među visokoškolskim profil ima samo 18 \% (Pažur 2019). 
svijetu vrlo bitna činjenica, a to je osobito važno naglasiti u kontekstu tako često ponavljanih iskustava nastavnika, knjižničara, ali i studenata, s kojima se susrećemo svaki dan, a koja započinju upitom korisnika knjižničaru o literaturi za seminar, jer „na Googleu nema ništa“... Stoga, unatoč uvriježenim činjenicama, spoznaju studenata o tome da će u pronalaženju literature $\mathrm{i}$ informacija imati bolje rezultate nakon posjeta knjižnici ili kontaktiranja $s$ knjižničarima, no što će rezultirati „googlanjem“ naslova, svakako valja naglasiti kao vrijednu.

\section{2 Ocjenjivanje zadovoljstva korisnika knjižničnih usluga}

Ekonomska literatura slaže se u činjenici da se otprilike $96 \%$ svih primatelja neke usluge koji nisu zadovoljni neće nikada naglas požaliti isporučitelju te usluge, no $90 \%$ od njih nikada se više neće ni vratiti na mjesto nezadovoljstva. Štoviše, svaki korisnik od ovih $90 \%$ koji se nikada više neće vratiti svoje će loše iskustvo podijeliti s najmanje 9 drugih osoba, od kojih će $13 \%$ to isto iskustvo podijeliti s čak 20 i/ili više drugih osoba. Dakle, ako u mjesec dana u knjižnici imamo 10 nezadovoljnih korisnika, među njima ćemo čuti pritužbu samo od jednog; pritom nećemo biti ni svjesni da naši korisnici nisu zadovoljni našom knjižnicom i njezinim uslugama. Nakon mjesec dana najmanje će 101 osoba znati da naša knjižnica ne pruža dobru uslugu (Carr 1990, prema Petr Balog, Gašo, 2016:63).

U nastavku su prikazani rezultati ocjenjivanja zadovoljstva korisnika knjižničnih usluga. Rezultati se odnose na ocjenu stupnja važnosti knjižničnih usluga, ocjenu stupnja zadovoljstva korisnika knjižničnih usluga, ocjenu uvjeta rada i ocjenu namjera ponašanja.

Tablica 2. Ocjena stupnja važnosti knjižničnih usluga

\begin{tabular}{|l|c|c|}
\hline Varijabla & Aritmetička sredina & Standardna devijacija \\
\hline Pronalazak odgovarajuće literature & 4,54 & 0,750 \\
\hline Online katalog & 3,44 & 1,128 \\
\hline Pretraživanje baza podataka & 3,51 & 1,303 \\
\hline $\begin{array}{l}\text { Rezervacija i obavijesti o dostupnosti knjiga } \\
\text { (e-mailom, telefonom, SMS-om) }\end{array}$ & 4,02 & 1,145 \\
\hline $\begin{array}{l}\text { Edukacija korisnika o pretraživanju } \\
\text { knjižničnih kataloga i baza podataka }\end{array}$ & 3,99 & 1,049 \\
\hline $\begin{array}{l}\text { Utjecaj knjižničnih usluga na osobni, stručni i } \\
\text { akademski razvoj }\end{array}$ & 4,23 & 0,776 \\
\hline
\end{tabular}

Napomena: ljestvica ocjenjivanja obuhvaća 5 ocjena, gdje ocjena 1 znači „posve nevažno“, a ocjena 5 „vrlo važno“.

Izvor: autorice (2020)

Prema rezultatima u tablici 2 zaključuje se da studenti najvažnijim cijene pronalazak odgovarajuće literature (aritmetička sredina = 4,54), dok je druga po važnosti usluga povezana uz dostupnost i rezervaciju literature koja im je potrebna (aritmetička sredina $=4,02$ ). Važna usluga je i ona vezana 
uz edukaciju korisnika u pretraživanju knjižničnih kataloga i baza podataka (aritmetička sredina $=3,99)$. Pretraživanje baza podataka i online katalog rangirani su kao osrednje važne knjižnične usluge.

Ujedno, ispitanici smatraju da knjižnične usluge imaju važan utjecaj na njihov osobni, stručni i akademski razvoj.

Tablica 3. Ocjena zadovoljstva korisnika knjižničnih usluga

\begin{tabular}{|l|c|c|}
\hline Varijabla & Aritmetička sredina & Standardna devijacija \\
\hline Čitaonica & 4,03 & 1,197 \\
\hline Računalna oprema & 3,80 & 1,204 \\
\hline Radno vrijeme & 3,56 & 1,352 \\
\hline Edukacija u pronalaženju informacija & 4,13 & 0,933 \\
\hline Knjižnična građa & 4,20 & 0,934 \\
\hline Dostupnost časopisa & 4,05 & 1,047 \\
\hline Susretljivost i ljubaznost osoblja & 4,74 & 0,554 \\
\hline Brzina pružanja zatražene informacije & 4,64 & 0,792 \\
\hline Ukupno zadovoljstvo & 4,55 & 0,946 \\
\hline
\end{tabular}

Napomena: ljestvica ocjenjivanja obuhvaća 5 ocjena, gdje ocjena 1 znači „vrlo nezadovoljan“, a ocjena 5 „vrlo zadovoljan“.

Izvor: autorice (2020)

Prosječne ocjene zadovoljstva korisnika knjižničnih usluga kreću se od 3,56 do 4,74 te pokazuju visok stupanj zadovoljstva pojedinim elementom usluge. Prema dobivenim rezultatima, korisnici su najzadovoljniji susretljivošću i ljubaznošću osoblja (aritmetička sredina $=4,74$ ) te brzinom kojom mogu dobiti zatraženu informaciju (aritmetička sredina $=4,64$ ). Korisnici knjižnice najmanje su zadovoljni radnim vremenom, iako taj element usluge nije ocijenjen negativno (aritmetička sredina $=3,56$ ), te prosječna ocjena pokazuje osrednje zadovoljstvo radnim vremenom.

Ukupno zadovoljstvo korisnika knjižničnih usluga ocijenjeno je prosječnom ocjenom 4,55, što pokazuje da su ispitanici, sveukupno gledajući, vrlo zadovoljni uslugama u promatranoj knjižnici.

Tablica 4 ujedno pokazuje da je oko 90 \% ispitanika zadovoljno ili vrlo zadovoljno knjižničnim uslugama, dok ih 5,5\% ima neutralan stav.

Tablica 4. Distribucija odgovora za varijablu „ukupno zadovoljstvo“

\begin{tabular}{|c|c|}
\hline Stupanj zadovoljstva & Struktura (\%) \\
\hline Vrlo nezadovoljan & 4,4 \\
\hline Nezadovoljan & 0,0 \\
\hline Niti zadovoljan niti nezadovoljan & 5,5 \\
\hline Zadovoljan & 16,5 \\
\hline Vrlo zadovoljan & 73,6 \\
\hline
\end{tabular}

Izvor: autorice (2020) 
Tablica 5 sadrži prosječne ocjene uvjeta rada u knjižnici.

Tablica 5. Ocjena uvjeta rada u knjižnici

\begin{tabular}{|c|c|c|}
\hline Varijabla & Aritmetička sredina & Standardna devijacija \\
\hline Prostor za individualni rad & 2,51 & 1,345 \\
\hline Dulje radno vrijeme & 3,16 & 1,401 \\
\hline Više računala & 2,68 & 1,124 \\
\hline Bolje opskrbljena građom & 2,71 & 1,508 \\
\hline Edukacije o korištenju građe & 2,71 & 1,401 \\
\hline Pomoć pri pisanju rada & 3,55 & 1,455 \\
\hline
\end{tabular}

Napomena: ljestvica ocjenjivanja obuhvaća 5 ocjena, gdje ocjena 1 znači „u potpunosti se ne slažem“, a ocjena 5 „u potpunosti se slažem".

Izvor: autorice (2020)

Rezultati iz tablice 5 pokazuju da se ispitanici uglavnom slažu da bi knjižnica trebala pružati pomoć pri pisanju stručnog ili znanstvenog rada (aritmetička sredina $=3,55$ ), dok o ostalim uvjetima rada imaju neutralan stav (aritmetičke sredine kreću se od 2,51 do 3,16).

Tablica 6. Ocjena lojalnosti korisnika knjižnice

\begin{tabular}{|c|c|c|}
\hline Varijabla & Aritmetička sredina & Standardna devijacija \\
\hline Preporuka kolegama & 4,43 & 0,701 \\
\hline Usklađenost s očekivanjima & 3,84 & 0,873 \\
\hline
\end{tabular}

Napomena: ljestvica ocjenjivanja obuhvaća 5 ocjena, gdje ocjena 1 znači „u potpunosti se ne slažem“, a ocjena 5 „u potpunosti se slažem".

Izvor: autorice (2020)

Tablica 6 sadrži prosječne ocjene lojalnosti korisnika knjižnice. Rezultati pokazuju visoku lojalnost korisnika prema korištenju usluga u promatranoj knjižnici, što podrazumijeva pozitivnu usmenu predaju (preporuka) i usklađenost s očekivanjima.

\section{3 Razlike u ocjenama važnosti knjižničnih usluga i zadovoljstva korisnika s obzirom na razinu studija ispitanika}

Slijedi analiza razlika u prosječnim ocjenama važnosti knjižnični usluga s obzirom na razinu studija ispitanika. U tablici 7 prikazani su rezultati t-testa. ${ }^{?}$

9 Prema Morgan et al. (2004.), t-test je robusna metoda, te ga se može upotrebljavati i u slučajevima da podaci nisu normalno distribuirani, a da se pri tome ne našteti valjanosti samog testa. Slijedom toga, opravdano je primijeniti ovu metodu i na podacima u ovom istraživanju. 
Tablica 7. Usporedba prosječnih ocjena važnosti knjižničnih usluga s obzirom na razinu studija ispitanika

\begin{tabular}{|c|c|c|c|c|}
\hline Varijabla & $\begin{array}{c}\text { Preddiplomski } \\
\text { studij (A. S.) }\end{array}$ & $\begin{array}{c}\text { Diplomski studij } \\
\text { (A. S.) }\end{array}$ & T-test & Sig. \\
\hline $\begin{array}{c}\text { Pronalazak odgovarajuće } \\
\text { literature }\end{array}$ & 4,65 & 4,38 & 1,713 & 0,090 \\
\hline Online katalog & 3,44 & 3,44 & 0,027 & 0,979 \\
\hline $\begin{array}{c}\text { Pretraživanje baza podataka } \\
\text { Rezervacija i obavijesti o } \\
\text { dostupnosti knjiga (e-mailom, } \\
\text { telefonom, SMS-om) }\end{array}$ & 3,65 & 3,31 & 1,258 & 0,212 \\
\hline $\begin{array}{c}\text { Edukacija korisnika o } \\
\text { pretraživanju knjižničnih } \\
\text { kataloga i baza podataka }\end{array}$ & 4,17 & 3,82 & 1,398 & 0,167 \\
\hline $\begin{array}{c}\text { Utjecaj knjižničnih usluga na } \\
\text { osobni, stručni i akademski } \\
\text { razvoj }\end{array}$ & 4,21 & 3,69 & 2,398 & $0,019^{*}$ \\
\hline
\end{tabular}

Napomena: A. S. - aritmetička sredina, tj. prosječna vrijednost; ${ }^{*}$ - značajnost razlike na razini $p=0,05$.

Izvor: autorice (2020)

Ocjene važnosti pojedinih knjižničnih usluga pokazuju da ispitanici s obje razine studija najveću važnost pridaju pronalasku odgovarajuće literature. S druge strane, korisnicima koji studiraju na preddiplomskom studiju najmanje je važna usluga online kataloga, dok je korisnicima na diplomskoj razini studija najmanje važno pretraživanje baza podataka. Ispitanici koji studiraju na preddiplomskom studiju su svim promatranim elementima knjižničnih usluga pridali veću važnost u usporedbi s korisnicima na diplomskom studiju.

Rezultati t-testa pokazuju da su uočene razlike slučajne, tj. nisu statistički značajne za većinu promatranim knjižničnih usluga. Statistički značajna razlika postoji samo za ocjenu važnosti edukacije korisnika o pretraživanju knjižničnih kataloga i baza podataka. Prema tome, ispitanici na različitim razinama studija razložito ocjenjuju važnost edukacija. Korisnici knjižničnih usluga koji studiraju na preddiplomskom studiju pridaju edukaciji o pretraživanju knjižničnog kataloga i baza podataka značajno veću važnost u usporedbi s onima koji studiraju na diplomskoj razini studija. Pretpostavka je da su studenti na diplomskim studijima vještiji i obrazovaniji u smislu informacijske pismenosti i da su edukaciju koju Knjižnica nudi pohodili u ranijim godinama studiranja, pa im dodatna edukacija na tom polju više znači u smislu individualnog osposobljavanja povezanog uz konkretan problem. 
Sljedeća tablica sadrži rezultate analize razlika prosječnih ocjena zadovoljstva korisnika knjižničnih usluga s obzirom na razinu studija ispitanika.

Tablica 8. Usporedba prosječnih ocjena zadovoljstva korisnika knjižničnih usluga s obzirom na razinu studija ispitanika

\begin{tabular}{|l|c|c|c|c|}
\hline Varijabla & $\begin{array}{c}\text { Preddiplomski } \\
\text { studij (A. S.) }\end{array}$ & $\begin{array}{c}\text { Diplomski } \\
\text { studij (A. S.) }\end{array}$ & T-test & Sig. \\
\hline Čitaonica & 4,29 & 3,69 & 2,343 & $0,022^{*}$ \\
\hline Računalna oprema & 4,13 & 3,36 & 3,193 & $0,002^{* *}$ \\
\hline Radno vrijeme & 3,77 & 3,28 & 1,720 & 0,089 \\
\hline Edukacija u pronalaženju informacija & 4,33 & 3,87 & 2,359 & $0,020^{*}$ \\
\hline Knjižnična građa & 4,37 & 3,97 & 2,010 & $0,047^{*}$ \\
\hline Dostupnost časopisa & 4,29 & 3,74 & 2,528 & $0,013^{*}$ \\
\hline Susretljivost i ljubaznost osoblja & 4,81 & 4,64 & 1,405 & 0,164 \\
\hline Brzina pružanja zatražene informacije & 4,84 & 4,39 & 2,480 & $0,016^{*}$ \\
\hline Ukupno zadovoljstvo & 4,52 & 4,59 & $-0,350$ & 0,727 \\
\hline
\end{tabular}

Izvor: autorice (2020)

Prema rezultatima iz tablice 8 razvidno je kako su korisnici koji studiraju na preddiplomskim studijima najzadovoljniji brzinom pružanja zatražene informacije, dok su oni koji studiraju na diplomskim studijima najzadovoljniji susretljivošću i ljubaznošću osoblja. S druge strane, obje grupe ispitanika najmanje su zadovoljne radnim vremenom knjižnice. Ispitanici koji studiraju na preddiplomskom studiju su za sve promatrane knjižnične usluge izrazili viši stupanj zadovoljstva u usporedbi s onima koji studiraju na diplomskom studiju.

Rezultati t-testa pokazuju da su uočene razlike statistički značajne za šest promatranih varijabli. Prema tome, ispitanici na različitim razinama studija izražavaju različit stupanj zadovoljstva za usluge čitaonice, računalnu opremu, edukaciju o pronalaženju informacija, knjižnične građe, dostupnost časopisa i brzinu pružanja zatražene informacije. Korisnici knjižničnih usluga koji studiraju na preddiplomskom studiju značajno su zadovoljniji tim elementima knjižnične usluge u usporedbi s onima koji studiraju na diplomskoj razini studija.

Za ostale elemente knjižnične usluge (radno vrijeme te susretljivost i ljubaznost osoblja) uočene razlike su slučajne, tj. nisu statistički značajne. Može se zaključiti da se prosječne ocjene ispitanika s preddiplomskog studija ne razlikuju značajno od prosječnih ocjena ispitanika s diplomskog studija, tj. da korisnici s obje razine studija izražavaju sličnu razinu zadovoljstva radnim vremenom i susretljivosti i ljubaznosti osoblja.

Nadalje, korisnici koji studiraju na diplomskom studiju izrazili su viši stupanj ukupnog zadovoljstva knjižnicom od korisnika s preddiplomskog studija. Ipak, prema rezultatima t-testa, ta je razlika 
slučajna, tj. nije statistički značajna. Na temelju toga može se zaključiti da se prosječne ocjene ukupnog zadovoljstva ispitanika s preddiplomskog studija ne razlikuju značajno od prosječnih ocjena ispitanika s diplomskog studija. Prema tome, korisnici s obje razine studija izražavaju sličnu razinu ukupnog zadovoljstva knjižničnim uslugama.

\subsection{Povezanost zadovoljstva korisnika pojedinom knjižničnom uslugom i ukupnog zadovoljstva korisnika knjižnice}

Cilj primjene multiple regresijske analize je utvrditi prirodu povezanosti između zadovoljstva korisnika pojedinom knjižničnom uslugom i ukupnog zadovoljstva korisnika knjižnice. Pri tome pojedine knjižnične usluge predstavljaju nezavisne varijable, dok je ukupno zadovoljstvo korisnika knjižnice zavisna varijabla u regresijskom modelu.

Tablica 9. Rezultati multiple regresijske analize

\begin{tabular}{|l|c|c|c|c|}
\hline Pokazatelji & Vrijednost & & & \\
\hline Koeficijent multiple korelacije R & 0,785 & & & \\
\hline Koeficijent determinacije R & 0,616 & & & \\
\hline Prilagođeni R2 & 0,577 & & & \\
\hline Standardna pogreška procjene & 0,370 & & & \\
\hline F-vrijednost & 15,637 & & & \\
\hline Pouzdanost & 0,000 & & & \\
\hline & & & & \\
\hline Nezavisna varijabla & $\mathbf{b}$ & Beta & $\mathbf{t}$ & Sig. \\
\hline Konstanta & 1,363 & & 3,849 & $0,000^{*}$ \\
\hline Čitaonica & $-0,216$ & $-0,458$ & $-3,338$ & $0,001^{*}$ \\
\hline Računalna oprema & 0,121 & 0,256 & 1,995 & $0,050^{* *}$ \\
\hline Radno vrijeme & 0,133 & 0,321 & 3,329 & $0,001^{*}$ \\
\hline Edukacija u pronalaženju informacija & 0,033 & 0,054 & 0,296 & 0,768 \\
\hline Knjižnična građa & 0,156 & 0,258 & 1,843 & 0,069 \\
\hline Dostupnost časopisa & $-0,153$ & $-0,283$ & $-2,397$ & $0,019^{* *}$ \\
\hline Susretljivost i ljubaznost osoblja & 0,884 & 0,877 & 8,209 & $0,000^{*}$ \\
\hline Brzina pružanja zatražene informacije & $-0,229$ & $-0,319$ & $-2,414$ & $0,018^{* *}$ \\
\hline
\end{tabular}

Napomena: zavisna varijabla: ukupno zadovoljstvo; ${ }^{*}$ - značajno na razini $p=0,01$; $^{* *}$ - značajno na razini $p=0,05$.

Izvor: autorice (2020)

Rezultati multiple regresijske analize pokazuju jaku, pozitivnu i statistički značajnu povezanost između zadovoljstva korisnika pojedinom knjižničnom uslugom i ukupnog zadovoljstva korisnika knjižnice $(R=0,785, p<0,01)$. Vrijednost koeficijenta determinacije $\left(R^{2}\right)$ pokazuje da se $61,6 \%$ varijance ukupnog zadovoljstva korisnika knjižnice može predvidjeti (objasniti) kombinacijom promatranih pojedinačnih knjižničnih usluga. 
Nadalje, prema rezultatima u tablici 9, šest od osam nezavisnih varijabli značajno utječe na zavisnu varijablu. Najvišu značajnu vrijednost ima varijabla „susretljivost i ljubaznost osoblja“ $(\beta=0,877, p<0,01)$, što znači da je ona najvažnija nezavisna varijabla u promatranom modelu, te najviše utječe na ukupno zadovoljstvo korisnika knjižnice. Slijede varijable „čitaonica“ ( $\beta=-0,458$, $p<0,01)$, ,radno vrijeme" $(\beta=0,321, p<0,01)$, „brzina pružanja zatražene informacije" ( $\beta=-0,319$, $p<0,05)$. Najmanje važne nezavisne varijable u ovom regresijskom modelu su „dostupnost časopisa“ ( $\beta=-0,283, p<0,05)$ i „računalna oprema“ $(\beta=0,256, p<0,05)$, zbog čega ovi elementi knjižnične usluge imaju najmanji utjecaj na ukupno zadovoljstvo korisnika knjižnice.

Sobzirom na to da je cjelokupni regresijski model statistički značajan ( $F=15,637, p<0,01)$, može se zaključiti da su pojedine knjižnične usluge značajno i pozitivno povezane s ukupnim zadovoljstvom, tj. da zadovoljstvo čitaonicom, računalnom opremom, radnim vremenom, edukacijom u pronalaženju informacija, knjižničnom građom, dostupnošću časopisa, susretljivošću i ljubaznošću osoblja te brzinom pružanja zatražene informacije mogu značajno predvidjeti ukupno zadovoljstvo korisnika knjižnice.

\section{5 Povezanost ukupnog zadovoljstva korisnika knjižnice i njihove lojalnosti}

Priroda povezanosti ukupnog zadovoljstva korisnika knjižnice i njihove lojalnosti prema knjižničnim uslugama ispitana je jednostavnom regresijskom analizom. Rezultati su prezentirani u tablici 10.

Tablica 10. Rezultati jednostavne regresijske analize

\begin{tabular}{|l|c|c|c|c|}
\hline Pokazatelji & Vrijednost & & & \\
\hline Koeficijent korelacije R & 0,344 & & & \\
\hline Koeficijent determinacije R & 0,119 & & & \\
\hline Prilagođeni R2 & 0,109 & & & \\
\hline Standardna pogreška procjene & 0,662 & & & \\
\hline F-vrijednost & 11,983 & & & \\
\hline Pouzdanost & 0,001 & & & \\
\hline & & & & \\
\hline Nezavisna varijabla & b & Beta & t & Sig. \\
\hline Konstanta & 3,266 & & 9,528 & $0,000^{*}$ \\
\hline Ukupno zadovoljstvo & 0,255 & 0,344 & 3,462 & $0,001^{*}$ \\
\hline
\end{tabular}

Napomena: zavisna varijabla: lojalnost; ${ }^{*}$ - značajno na razini $p=0,01$.

Izvor: autorice (2020)

Rezultati u tablici 10 pokazuju statistički značajnu povezanost između ukupnog zadovoljstva korisnika knjižnice i njihove lojalnosti $(F=11,983, p<0,01)$.

Prema koeficijentu korelacije ( $R=0,344)$, postoji slaba i pozitivna veza između zadovoljstva i lojalnosti korisnika knjižnice. Vrijednost koeficijenta determinacije $\left(R^{2}\right)$ pokazuje da se $11,9 \%$ varijance u varijabli „lojalnost“ može predvidjeti varijablom „ukupno zadovoljstvo korisnika“. 


\section{6 Rasprava i preporuke za buduća istraživanja}

U raspravi o rezultatima i eventualnim ograničenjima ukazujemo na nekoliko zanimljivosti.

Ograničenja istraživanja koja su, kako je već obrazloženo, djelomično intencionalna u usmjerenju na samo one ispitanike koji koriste prostor Knjižnice, mogu ukazati na mali broj anketiranih korisnika, čime se otvara prostor novim pitanjima, jer se zanimljivim predmnijeva proširiti krug ispitanika i uključiti u anketu sve kategorije korisnika. $U$ tom smislu bismo, u daljnjem, inauguriranom istraživanju, uključili e-anketom i mišljenja o zadovoljstvu pruženim uslugama, nazovimo ih tako, e-korisnika, tj. korisnika koji rjeđe borave u knjižnici i najčešće s njenim osobljem komuniciraju e-poštom. Također bi bilo dobro obuhvatiti stavove nastavnog osoblja, s obzirom na to da njihova poimanja kvalitetne usluge i očekivanja, tj. zadovoljstvo dobivenim uslugama polazi od djelomično različitih premisa. Naime, ovo istraživanje naglasilo je važnost koju studenti korisnici knjižnice pridaju pronalasku odgovarajuće literature. Budući da je strategija nabave knjižnične građe tako osmišljena da se nabavljaju gotovo svi dobavljivi naslovi čiju nabavu nastavnici iniciraju, pretpostavka je da će njihova očekivanja biti posljedično povezana s navedenim. Naime, zahtjev nastavnika za nabavom literature gotovo uvijek rezultira kupovinom knjiga, ili barem međuknjižničnom posudbom, ako je građu nemoguće drugačije nabaviti. Upravo stoga nastavnici kao korisnici mogu drugačije odgovoriti na pitanje jesu li zadovoljni knjižničnim fondom, tj. ima li knjižnica svu potrebnu građu. S druge strane, studenti rijetko iniciraju nabavu građe, kada iznimno ukažu na nedostatak naslova koji je istaknut na popisu literature određenog kolegija, nakon čega se, suradnjom nastavnika i knjižničarke, knjige nastoji nabaviti. Jedan od rezultata ispitivanja analize zadovoljstva svakako će biti i jasnije poticanje studenata, nastavnika i knjižničara na zajedničku suradnju i bržu komunikaciju prilikom nabave nove ispitne literature.

Zaključak ankete koji podvlači zadovoljstvo korisnika brzinom kojom mogu dobiti zatraženu informaciju također treba naglasiti, osobito povezanu uz visok stupanj zadovoljstva koje iskazuju prema susretljivosti i ljubaznosti osoblja. Naime, ovaj odgovor potvrđuje da su korisnici prepoznali važnost brzine komunikacije u savjetovanju o građi. Dobrodošlo je u tom smislu savjetovanje sa stručnom osobom i pritom brža komunikacija u vezi s posudbom (potvrđivanje rezervacije e-mailom i telefonom, obavijesti o dolasku rezervirane građe u Knjižnicu e-mailom i SMS-om, te stoga i brzo posuđivanje građe dok su studenti još u zgradi na predavanju i sl.).

Istraživanje zadovoljstva studenata također je naglasilo i istaklo važnost usluge knjižnice kao centra edukacije korisnika u pretraživanju knjižničnih kataloga i baza podataka. lako je dosadašnja praksa Knjižnice na tom području pružala studentima četiri vrste edukacije, različite forme, sadržajnog 


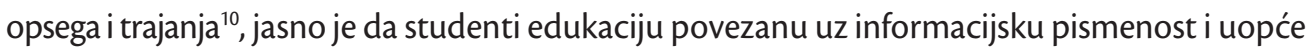
edukaciju o knjižničnim uslugama ${ }^{11}$ poimaju kao vrlo bitnu u svom školovanju.

Osrednje zadovoljstvo koje studenti iskazuju uvjetima rada Knjižnice ističe moguće nedostatke prostora čitaonice u kojoj, zbog česte gužve, ponekad nedostaje prostora za individualni rad. Ovaj podatak nije nov, pojavio se i u opsežnijim prethodnim istraživanjima, u kojima se također dokazala važnost potrebe za izdvojenim prostorom za miran rad i koncentraciju pri učenju, bez obzira kakav prostor ima čitaonica (Allen et al., 2010; Yoo-Lee et al., 2013). Osrednje zadovoljstvo računalnom opremljenošću Knjižnice odražava se zapravo kao manji nedostatak, budući da Veleučilište ima dvije računalne učionice, no korisnici su naučeni posjećivati Knjižnicu, dijelom i zbog usluga i dostupne građe. Što se tiče niže razine zadovoljstva radnim vremenom, može se pretpostaviti da je ona povezana s različitim smjenama u kojima se održavaju predavanja ili s različitim očekivanjima studenata s obzirom na pretpostavljenu veličinu i radno vrijeme knjižnica iz kojih dolaze.

Nadalje, rezultati upućuju da je zadovoljstvo korisnika pojedinom knjižničnom uslugom značajno i pozitivno povezano s ukupnim zadovoljstvom korisnika knjižnice. Zaključuje se kako veće zadovoljstvo čitaonicom, računalnom opremom, radnim vremenom, edukacijom u pronalaženju informacija, knjižničnom građom, dostupnošću časopisa, susretljivošću i ljubaznošću osoblja te brzinom pružanja zatražene informacije dovodi do većeg ukupnog zadovoljstva korisnika knjižnice. Pri tome najvažniju ulogu u postizanju ukupnog zadovoljstva ima susretljivost i ljubaznost osoblja.

Osim toga, rezultati ovog istraživanja također pokazuju pozitivnu i značajnu vezu između zadovoljstva i lojalnosti korisnika knjižnice, ukazujući da veće zadovoljstvo korisnika knjižnice rezultira njihovom lojalnošću, tj. to će radije preporučiti usluge knjižnice drugim kolegama.

\section{ZAKLJUČAK}

Istraživanje je nastalo kao produkt strategije Knjižnice Veleučilišta u Rijeci da stalno pokušava unaprijediti kvalitetu svojih usluga i svoga poslovanja, čiji je važan dio i analiza istraživanja zadovoljstva korisnika. Nakon više desetaka parcijalnih anketa na manjem uzorku koje su istraživale zadovoljstvo korisnika manjim inovacijama u poslovanju Knjižnice, ovo je prvi opširniji istraživački ciklus pri čijem su planiranju, početkom 2020., autorice predmnijevale otvoriti prostor za dodatnim, proširenim, nastavkom. Ta je godina otvorila vrata za još jedno područje istraživanja, osobito za

10 Najkraće, polusatno upoznavanje studenata s Knjižnicom održava se u listopadu; knjižničarka posjećuje svaku studijsku grupu na prvom semestru stručnog studija i ukratko upoznaje studente s mrežnim stranicama Knjižnice, načinima pretraživanja kataloga i najznačajnijim bazama podataka za sadržaje koji se uče na specifičnom studiju, a čije se poveznice nalaze na mrežnim stranicama Knjižnice. Sadržajnije, tjedne radionice Kako do željene literature studentima se nude tijekom semestra, no primijećeno je da, unatoč brojnim prijavama na radionice, studenti u konačnici teško usklađuju rasporede. Stoga se u Knjižnici održava i treći tip radionica, za manje grupice studenata, koje obuhvaćaju pretraživanja vezana uz određene uže tematske interese. Konačno, tu su i radionice prilagođene individualnim tematskim pretraživanjima, poput konzultacija, na koje studenti dolaze na neku vrst korekcije popisa literature koju su pronašli sami, a koju će knjižničarka nadopuniti savjetovanim dodatnim naslovima, jer se studente potiče i uči samostalnom pretraživanju kako bi se, po diplomi, znati snaći u moru stručne i manje stručne literature.

11 Osim spomenutih ciklusa radionica, kao dio edukacije navodimo uslugu e-mailom Pitajte knjižničare, radionice vezane uz informacijsku pismenost, informacijske letke o osnovnim informacijama o knjižničnim uslugama, ankete o zadovoljstvu korisnika novouvedenim inovacijama i sl. 


\section{S. Grakalić Plenković, S. Raspor Janković: Istraživanje zadovoljstva korisnika visokoškolske knjižnice Zbornik Veleučilišta u Rijeci, Vol. 9 (2021), No. 1, pp. 97-117}

knjižničare, jer su zbog pandemije i naglog prelaska na online nastavu knjižnice velikim naporima nastojale korisnicima otvoriti svoja vrata. Čini se, naime, korisnim, u daljnjem istraživanju, u smislu uočavanja suvremenih trendova i promjena u radu visokoškolskih knjižnica, ovo istraživanje nadopuniti iskazivanjem stavova korisnika o poslovanju online u posebnim uvjetima i dodatnom poboljšanju i prilagodbi.

Zaključno ističemo da ovo istraživanje ostavlja prostora za nadopunu i proširenje, dok će njegovi rezultati poslužiti u promišljanju o mogućim poboljšanjima usluga u praktičnom smislu, budući da će poslužiti kao opravdana motivacija u donošenju odluka vezanih uz prerazmještaj prostora Knjižnice i redefiniranje postojećeg. Promjene će sada biti temeljene na pouzdanim informacijama, ne pretpostavljenim željama korisnika i zaposlenika Knjižnice, pa bi, primjerice, dio studentskih prijedloga mogao biti prihvaćen i moglo bi se stvoriti manje odvojenih i mirnijih radnih mjesta za individualni rad ili rad u parovima, no, ovisno o financijskim i prostornim ograničenjima, manje je vjerojatno da će se uspjeti proširiti prostor same čitaonice.

Procjena postojećeg stanja mogla bi nadopuniti procedure i strategije nabave i širenja knjižničnog fonda i time usluge koje Knjižnica nudi studentima. Naime, stavovi studenata iskazani stupnjem zadovoljstva u anketi, povezani s knjižničnom građom (dostupnost odgovarajuće literature i fond knjižnice), uvjetima rada u Knjižnici (prostorom, računalnom opremom, radnim vremenom), mišljenja o radu knjižničnog osoblja (stručnost, susretljivost), kvalitetom i brzinom informacija (pretraživanja, rezervacije, obavijesti i brzina usluge) te mogućnosti edukacije koje Knjižnica nudi (pretraživanje kataloga, pomoć pri pronalaženju građe, radionice koje promiču informacijsku pismenost, radionice povezane s izradom seminarskih radova, osnova pismenosti i sl.) pomoći će u formiranju zaključaka o utemeljenju pretpostavke da korisnici Knjižnicu Veleučilišta u Rijeci doživljavaju kao važno informacijsko središte u procesu studiranja i svog znanstvenog i stručnog rada, te da su, sukladno tome, zadovoljni uslugama koje ona pruža.

\section{LITERATURA}

Allen, D. B. et al. (2010) „K-state's distributed learning commons: achieving long-term sustainability through strategic partnership", College \& Undergraduate Libraries, 17(2/3), p. 160-176

Aleksić, Lj., Seiter-Šverko, D. (2014) „Vrednovanje Nacionalne i sveučilišne knjižnice u Zagrebu s gledišta korisnika“, Vjesnik bibliotekara Hrvatske, 57(4), p. 1-44

Atkinson, J. (2017) „Academic Libraries and Quality: An Analysis and Evaluation Framework“, New Review of Academic Librarianship, 23(1), p. 00-00. doi: 10.1080/13614533.2017.1316749

AZVO. Postupci vrednovanja u visokom obrazovanju; Ishodi provedenih vrednovanja. https://www.azvo.hr/hr/ vrednovanja/postupci-vrednovanja-u-visokom-obrazovanju/reakreditacija-visokih-ucilista/rezultati-vrednovanjarvu (5. 11. 2020.).

Badurina, B., Dragija-Ivanović, M., Krtalić, M. (2010) „Vrednovanje knjižničnih službi i usluga akademskih i narodnih knjižnica", Vjesnik bibliotekara Hrvatske, 53(1), p. 47-63

Barada, V., Zdravković, Ž. (2009) „Anketno istraživanje zadovoljstva korisnika/ca Gradske knjižnice Zadar“. U: Izvještaj. Zadar: Gradska knjižnica Zadar (dostupno na http://www.gkzd.hr/pdf/dokumenti/GKZD_Anketa_Izvjestaj2009. pdf) (5. 10. 2020.)

Candy, P., Crebert, G., O'Leary, J. (1994) Developing lifelong learners through undergraduate education, Canberra: Australian Government Publishing Service 
Coker, B. (2013) "Antecedents to website satisfaction, loyalty, and word-of-mouth", Journal of Information Systems and Technology Management, 10(2), p. 209-218

Choshaly, S. H., Mirabolghasemi, M. (2018) „Using SEM-PLS to assess users satisfaction of library service quality: evidence from Malaysia“, Library Management, 4(10). doi: 10.1108/LM-03-2018-0023

Dewey, J. (1997) Experience and education, New York: MacMillan Publishing Co.

Dukić, G., Hasenay, S., Mokriš Marendić, S. (2009) „Analiza zadovoljstva korisnika/studenata u knjižnicama Prehrambenotehnološkog i Pravnog fakulteta te u Gradskoj i sveučilišnoj knjižnici Osijek", Vjesnik bibliotekara Hrvatske, 52(1/4), p. $172-187$

Europska komisija. Obrazovanje i izobrazba. Relevantno i visokokvalitetno visoko obrazovanje.

http://ec.europa.eu/education/policy/higher-education/quality-relevance_hr (5. 11.2020.)

Fornell, C. (1992) „A National Customer Satisfaction Barometer: The Swedish Experience“, Journal of Marketing, 56(Januray), p. 6-21

Franculić, M. (2018) „Analiza rezultata provedene ankete o zadovoljstvu korisnika uslugama Gradske knjižnice i čitaonice Požega", Knjižničarstvo: glasnik Društva knjižničara Slavonije, Baranje i Srijema, 22(1/2), p. 9-28

Giese, J. L., Cote, J. A. (2000) „Defining Customer Satisfaction“, Academy of Marketing Science Review, (1) (dostupno na http://www.amsreview.org/articles/giese01-2000.pdf) (27. 11. 2020.)

Golenko, D., Arh, E. (2020) „Programi informacijskog opismenjavanja (teorijski okviri u području prava i medicine)“, Bosniaca: časopis Nacionalne i univerzitetske biblioteke Bosne i Hercegovine, 25(25), p. 17-41. doi: 10.37083/ bosn.2020.25.17

Gómez-Cruz, M. E. (2019) „Electronic reference services: a quality and satisfaction evaluation“, Reference Services Review, 47(2), p. 118-133. doi:10.1108/rss-07-2018-0057

Kandampully, J., Suhartanto, D. (2000( „Customer loyalty in the hotel industry: the role of customer satisfaction and image", International Journal of Contemporary Hospitality Management, 12(6), p. 346-351

Kiran, K., Diljit, S. (2011) „Antecedents of customer loyalty: Does service quality suffice?”, Malayesian Journal of Library and Information Science, 16(2), p. 95-113.

Lau, J. (2011) Smjernice za informacijsku pismenost u cjeloživotnom učenju: završna verzija, recenzirano 30. srpnja 2006. [s engleskog prev. Ivana Faletar], Zagreb: Hrvatsko knjižničarsko društvo

Martek, A., Krajna, T., Fluksi, T. (2009) „Koliko je zapravo dobra vaša knjižnica?". U: Uspostava kvalitete u specijalnim i visokoškolskim knjižnicama - knjižnice u bolonjskom okruženju: Zbornik radova 10. dani specijalnih i visokoškolskih knjižnica. Zagreb: Hrvatsko knjižničarsko društvo, p. 11-23

McKnight, S. (2006) Customers value research. // Management, marketing and promotion of library services based on statistics, analyses and evaluation. München, 2006, 206-216.

Mi, J., Nesta, F. (2006) „Marketing library services to the net generation“, Library management, 27(6/7), p. 411-422

Morgan, A. G. et al. (2004) SPSS for Introductory Statistics: Use and Interpretation, 2nd Edition, New Jersey: Lawrence Erlbaum Associates Publishers

Moslavac, A. (2017) „U traganju za kvalitetom visokoškolske knjižnice - primjer knjižnice Filozofskog fakulteta Sveučilišta u Rijeci", Vjesnik bibliotekara Hrvatske 60(4), p. 95-124

Novak, H. (2010) „Anketno istraživanje zadovoljstvo korisnika Gradske knjižnice Zadar“, Vjesnik bibliotekara Hrvatske, 53(3/4), p. 140-157

Oakleaf, M. (2010) Value of Academic Libraries: A Comprehensive Research Review and Report, Chicago: American Library Association

Oliver, R. L. (1997) Satisfaction: A Behavioral Perspective on the Customer, New York: McGraw-Hill

Pavičić, J., Alfirević, N., Aleksić, Lj. (2006) Marketing i menadžment u kulturi i umjetnosti, Zagreb: Masmedia. 
Pažur, I. (2019) „Knjižnični izvori i usluge za mobilne uređaje u visokoškolskim i srodnim knjižnicama“, Vjesnik bibliotekara Hrvatske, 62(2), p. 1-32

Petr, K. (2000) „Uspješnost poslovanja Knjižnice Pedagoškog fakulteta u Osijeku: zadovoljstvo korisnika Knjižnicom i njezinim uslugama", Vjesnik bibliotekara Hrvatske 43(4), p. 80-90

Petr Balog, K. (2010) Prema kulturi vrednovanja u visokoškolskim knjižnicama, Osijek: Filozofski fakultet.

Petr Balog, K., Dragija-Ivanović, M., Feldvari, K. (2010) “Percepcija kvalitete 'iznutra': razgovori s ravnateljima narodnih i voditeljima visokoškolskih knjižnica", Vjesnik bibliotekara Hrvatske 53(3/4), p. 1-24

Petr Balog, K., Plašćak, B. (2012) “Customer satisfaction at the Faculty of Philosophy Library in Osijek, Croatia”, Performance Measurement and Metrics 13(2), p. 74-91

Petr Balog, K., Gašo, G. (2016) „Istraživanje zadovoljstva korisnika u knjižnici Filozofskog fakulteta u Osijeku - uspijevamo li ih zadovoljiti?", Libellarium, 9(1), p. 59-88. doi: http://dx.doi.org/10.15291/libellarium.v9i1.243

Pikić, A. (2016) „Knjižnična podrška studentskom učenju i istraživanju: ocjena kvalitete hrvatskih visokoškolskih knjižnica u postupku reakreditacije visokih učilišta", Libellarium, 9(1), p. 111-112. doi: http://dx.doi.org/10.15291/libellarium. v9i1.287

Pikić, A. (2017) „Korisničke razlike u očekivanjima, procjeni dobivene usluge i zadovoljstvu: primjena LibQUAL+"'-a u Knjižnici Filozofskog fakulteta Sveučilišta u Zagrebu", Vjesnik bibliotekara Hrvatske, 60(4), p. 73-94

Radičević, V. (2013) “Samovrednovanje visokoškolske knjižnice - na primjeru Knjižnice Filozofskog fakulteta u Osijeku”, Knjižničarstvo, 17(1), p. 83-98

Špiranec, S., Banek Zorica, M. (2008) Informacijska pismenost: teorijski okvir i polazišta, Zagreb: Zavod za informaciijke studije Odsjeka za informacijske znanosti Filozofskog fakulteta Sveučilišta u Zagrebu

Vrana, R., Pavić, L. (2017) „Zadovoljstvo korisnika promidžbom i prepoznatljivošću Gradske knjižnice Rijeka“, Vjesnik bibliotekara Hrvatske, 60(2/3), p. 193-217

Yoo-Lee, E. Y., Heon Lee, T., Velez, L. (2013) „Planning library spaces and services for Millenials: an evidence-based approach", Library Management, 34(6/7), p. 498-511

$\mathrm{Xu}, \mathrm{F} . \mathrm{i} \mathrm{Du}, \mathrm{J}$. T. (2018) "Factors influencing user satisfaction and loyalty to digital libraries in Chinese universities", Computers in Human Behavior, 83, p. 64-72

Zeithaml, V., Bitner, M. J. (2003) Services Marketing: integrating customer focus across the firm, 3rd edition: McGrow-Hill

Zeithaml, V. A. (1988) „Customer perceptions of price, quality and value: a means-end model and synthesis of evidence", Journal of Marketing, 52(3), p. 2-22 


\title{
CUSTOMER SATISFACTION RESEARCH WITH LIBRARY IN HIGHER EDUCATION
}

\author{
Sanja Grakalić Plenković \\ PhD, Assistant Professor, Polytechnic of Rijeka, Vukovarska 58, 51000 Rijeka, Croatia; \\ e-mail: sgrakal@veleri.hr \\ Sanja Raspor Janković \\ PhD, College Professor, Polytechnic of Rijeka, Vukovarska 58, 51000 Rijeka, Croatia; \\ e-mail: sraspor@veleri.hr
}

\begin{abstract}
Evaluation of library services is the most objective way to determine library's organisation and performance. The purpose of this research was to examine customer satisfaction with library services. Primary data was gathered in Library of Polytechnic of Rijeka. Data was gathered using questionnaire that consisted of six parts: library services importance, customer satisfaction with particular library service, working conditions in library, overall customer satisfaction with library, behavioural intentions of library customers, and respondents' profile. Sample consists of graduate and postgraduate students. Data was gathered from January to November 2020. Data was analysed using descriptive statistics, $t$-test, and regression analysis. Descriptive analysis results showed importance of library staff, that has important role as the main source of information regarding the library services. The most important library service is finding the literature. Overall customer satisfaction's average score was 4,55, implying high level of customer satisfaction with the library. T-test results indicated that library customers who study at different study levels have significantly different customer satisfaction levels with particular library services. On the other hand, both groups of respondents have similar perceptions regarding overall customer satisfaction. In addition, customer satisfaction with particular services have significant effect on overall customer satisfaction with library services. Similarly, overall customer satisfaction significantly impacted behavioural intentions of library customers. Present research contributed to better understanding of library services perceptions, thus showing variety of suggestions for increasing library performance and working conditions. These should meet customers' needs, aiming to enhance customer satisfaction level and to achieve positive behavioural intentions of library customers.
\end{abstract}

Key words: customer satisfaction, library service quality, evaluation of library services, academic library, quantitative analysis 
